diagnostikk og differensialdiagnoser hos barn og voksne som presenterer allergiske symptomer fra luftveier, hud, øye, nese og/ eller mage-tarm-systemet. Når det gjelder behandling, presenteres både standardregimene og nyere immunmodulerende medikamenter. Avslutningsvis diskuterer man astma og allergi i lys av arbeidsmedisin og yrkesveiledning.

Her har altså forfatterne lykkes med å gå i dybden, samtidig som de beholder bredden i astma- og allergifeltet. Teksten er lettlest og ofte supplert med forklarende figurer og tabeller. Studiene gjenspeiler nordiske forhold, og forfatterne drøfter vanlige og mer sjeldne kliniske tilstander. Selv om boken nok i første omgang er rettet mot studenter eller blivende spesialister, tror jeg den også kan være til glede for mange som allerede er godt etablert i faget.

Monica C. Munthe-Kaas

Barnesenteret

Kvinne- og barnklinikken

Oslo universitetssykehus, Ullevål

\section{Dansk bok \\ i laboratoriemedisin}

Lyngbye J, Kjær A, Ladefoged SA et al, red Lyngbyes laboratoriemedicin

2. utg. 739 s, tab, ill. København: Nyt Nordisk Forlag Arnold Busck, 2010. Pris DKK 699 ISBN 978-87-17-04044-1

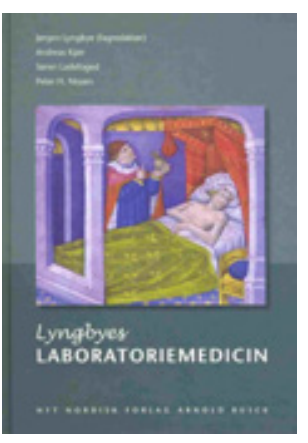

Dette er andre utgave av et oppslagsverk beregnet på medisinsk personale som tolker laboratorieresultater. Vekten er lagt på klinikk og i mindre grad på teknisk-kjemiske aspekter ved analysering. Særlig leger, bioingeniører og

studenter vil ha nytte av denne boken.

Etter en kort historisk oversikt kommer et kapittel på ca. 500 sider med en alfabetisk oversikt over komponenter som analyseres i forskjellige kroppsvæsker.

Deretter følger kapitler om nukleærmedisin, klinisk fysiologi og molekylær medisin. Referanselisten er på 95 sider, med referanser også fra 2009.

Det er Lyngbye som er hoved- og eneforfatter for den mest vesentlige delen på 500 sider. Fordelen ved å ha én forfatter er at gjentakelser unngås. Ulempen er at det kan være vanskelig for én person å ha egen erfaring med alle disse komponentenes betydning i klinikken.

Hver komponent beskrives i et ryddig system om hvilken bruk man har av komponenten, pasientforberedelser, prøvetaking, referanseintervaller, biologisk variasjon, tolkning og komponentens biokjemi/fysiologi. Dette er gjort på en meget omfattende og grundig måte.

Under biologisk variasjon savner man mer konkrete opplysninger om denne variasjonen i form av variasjonskoeffisienter. Sammen med analytisk variasjon kunne dette si noe om en komponents forandringer hos samme pasient er av praktisk betydning.

Kapitlet om nukleærmedisin er en skjematisk oppsummering av dette fagfeltet. Et bedre alternativ på norsk er Rootwelts Nuklecermedisin, selv om den nå er fem år gammel (1).

Kapitlet om klinisk fysiologi er på fire sider og kunne med hell ha vært utelatt.

Kapitlet om molekylær medisin er en innføring i moderne metoder basert på DNA- og RNA-isolering, illustrert ved en alfabetisk liste over sykdommer hvor disse analysene kan være aktuelle.

Referansene er litt uryddige. De finnes hovedsakelig i et eget kapittel, men også som fotnoter og direkte i teksten, ofte uten å være med i hovedlisten. Referansene er ordnet etter den komponenten de refererer til, men de kunne like gjerne ha vært plassert etter vedkommende komponent i hovedkapitlet.

På norsk finnes i ny utgave Brukerhåndbok i medisinsk biokjemi (2), som også har en nettutgave som oppdateres regelmessig. Et svensk alternativ er Laurells Klinisk kemi, som kommer i ny utgave høsten 2010. Et engelsk alternativ er Tietz textbook of clinical chemistry and molecular diagnostics (3).

Ett eller flere av disse alternativer er et bedre valg enn den foreliggende bok, fordi de med sine mange medforfattere sikrer en mer personlig erfaring med de komponentene som beskrives.

\section{Per Kr. Lund}

Oslo

\section{Litteratur}

1. Aas M. Oppdatert om nukleærmedisin. Anmeldelse av: Rootwelt K. Nukleærmedisin. Tidsskr Norske Lægeforen 2006; 126: 1230

2. Urdal P, Brun A, Åsberg A, red. Brukerhåndbok i medisinsk biokjemi. 4. utg. Haugesund: Akademisk fagforlag, 2009.

3. Burtis CA, Ashwood ER, Bruns DE, red. Tietz textbook of clinical chemistry and molecular diagnostics. 4. utg. Philadelphia PA: Elsevier Saunders, 2006

\section{Oppdatert kunnskap om arbeidsrettet rehabilitering}

Westerhäll LV, Bergroth A, Ekholm J, red. Rehabiliteringsvetenskap

Rehabilitering till arbetslivet i ett flerdisciplinärt perspektiv. 2. utg. 248 s, tab, ill. Lund: Studentlitteratur, 2009. Pris SEK 301 ISBN 978-91-44-05264-9

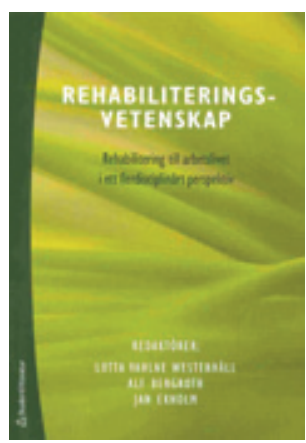

Boken er en ny utgivelse med de samme svenske forfatterne fra forskernettverket «Centrum for rehabiliteringsforskning», som sto for første utgivelse i 2006 (1). Den er rettet mot områder som rehabiliteringsviten-

skap, personell og arbeidslivsspørsmål, sosial og medisinsk jus, sosialarbeid, sosiologi og sosialmedisin. Formen er lærebokaktig, og det svenske velferdssystemet blir beskrevet på en måte som gjør teksten egnet som dokumentasjonsbase for ulike aktører innen de forskjellige feltene $\mathrm{i}$ arbeidsrettet rehabilitering.

Siden første bokutgivelse er dette fagområdet blitt enda mer aktualisert gjennom økt politisk fokusering, noe som igjen har ført til større behov for forståelse for sammenhengen mellom arbeidsevne, helse og arbeidskrav. Det vil da være nyttig å se dette i lys av WHOs definisjon av helse i ICF (International Classification of Functioning, Disability and Health). Det har kommet frem nye forskningsresultater når det gjelder effekten på sykmeldingsdager i forhold til organiserte, koordinerte prosesser fra de ulike etatene. I den forbindelse vises det til NAV-reformen som nettopp hadde til hensikt å forbedre samarbeidet mellom trygdeetat, arbeidsformidling og sosialtjeneste.

Noen kapitler er skrevet i en litt tung stil, med enkelte svenske ord som kan være vanskelig å forstå, men bruken av eksempler gjør det lettere å få med seg poengene. Det er brukt noen klargjørende, oppdaterte figurer og tabeller, men kanskje kunne boken vært bedre som opplagsbok dersom man hadde brukt figurer for å illustrere de ulike aktørenes rolle. Jeg savner også norske og danske referanser.

Det blir vist til at arbeidsrettet rehabilitering i form av planmessige, koordinerte tiltak med pasienten som aktiv deltaker, kan gi betydelige økonomiske innsparinger på samfunnsnivå, og også at slike tiltak kan være besparende i forhold til forbruk av helsetjenester.

Selv om forfatterne henvender seg til det svenske markedet, er boken nyttig for oss 